\title{
Patterns of Feminine Discourse in Samuel Beckett's Pas Moi
}

Dr. Marzia CAPORALE

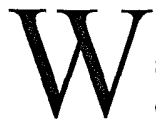

ith the exception of Oh les beaux jours, Samuel Beckett's theater from the 1960's on drastically moves towards a process of reduction of body and language. Pas moi, in this sense, fits the profile of Beckett's later works where minimalism is an essential part of both text and performance. On stage, there is no longer a character as such but only a portion of one. In this play, the protagonist is Bouche who, as her self-explanatory name states, is simply a mouth: the body of the woman who utters the eighteen-minute long tirade is completely hidden in the dark, absent at all effects and replaced only by her language. In front of her is a mysterious figure, Auditeur, who lacks both the physical and the linguistic consistency of a real character: he never speaks, at least audibly, and his body, as Beckett states in the stage directions, is wrapped in an ample robe, a djellaba which hides him and makes him virtually non-existent to the audience's eyes. Auditeur passively listens to the frantic speech of his counterpart, his only purposeful action being a hand gesture whose intent is to make Bouche use the first person pronoun "je" in place of "elle." 1

Critics have traditionally read Pas moi as an example of Beckett's distrust towards language and communication. Ann Wilson calls Bouche a "castrated voice" while Jude Meche defines her speech as "empty and obsessive." ${ }^{2}$ The critical doxa has almost unanimously perceived Bouche's 
linguistic paralysis and her inability to produce coherent speech as semiotic failure. From this perspective, the fragmentation of body and language of the mouth on stage leads to the character's inability to create a viable identity: broken words plus broken female body equals broken woman. Without denying Bouche's fragmented condition, I will argue that such fragments of body and language do not lead to empty or broken discursive practices and that they do not prevent the construction of a functioning feminine identity. In particular, my discussion of the play illustrates how the mouth in Pas moi achieves meaningful communication despite the character's elliptic presence on stage. Bouche's disorderly verbal stream addresses (and partly solves) fundamental questions linking female gender and subjectivity. She is a woman born into a cultural and linguistic pattern of masculine superiority: yet, she fights to gain access to a speech that may define her disjointed feminine self. In order to produce viable verbal communication, Bouche rejects a linguistic model made of chronologically linear events and replaces it with a communicative system built on broken logical connections, repetitions, and returns to better fit her fluid identity.

The play traces Bouche's painful steps towards linguistic selfrealization. Although late in life (she is soon to be seventy years old), she attempts to establish subjectivity through a mostly verbal practice, as her body alone cannot tell the story. Bouche's quest for an undivided identity takes the shape of a monologue, interrupted four times by Auditeur's gestural intervention ("quatre gestes brefs" 81). His silent reminder to Bouche to use the first person subject pronoun "je" while talking about herself is met regularly with a strong refusal on her part: "quoi? qui? Non... ! elle!" (82). Despite her emphatic rejection of "je," it is clear that, through her speech, Bouche is reliving her own personal experiences of isolation and estrangement. During her "confession," she admits that the words she utters are separate from her, that she has "aucune idée de ce qu'elle raconte," (87) thus displaying a clear disjunction of her "self" from the discursive practices she engages in. Bouche struggles with the impossibility of saying "I," as she can only be defined by something other than herself: either "elle" or the "not I" of the title. As Ann Wilson observes, "Mouth steadfastly refuses to inscribe herself as the fully present speaking subject but instead insists that the story is that of "she" (193). Indeed, this character has no choice but to speak in the third person. The use of the first person pronoun would not be adequate in representing her. If she were whole, she might be able to identify with such a pronoun: however, she is only a piece of a female body, a mouth who wants to speak but who must first acquire the linguistic tools that will allow her to do so. 
Born a woman and therefore "cursed" by her female condition, Bouche initially reproduces in her speech the schemes and parameters of a patriarchal discourse to which she only apparently subscribes. In reliving her most significant life events, Bouche recalls being the object (and the victim) of a strict and unchallengeable order which denied her any possibility of becoming a "speaker" for a long period of time. Her being destined to silence is implicit in the account of her birth, in which womanhood and nothingness are viewed as one and the same. As a woman, Bouche is destined to accomplish nothing of any value, as she admits: "monde ... mise au monde ... ce monde ... petit bout de rien ... avant l'heure ... loin de - quoi? ... femelle? ... oui ... petit bout de femelle" (82). ${ }^{3}$ The expressions "petit bout de rien" and "petit bout de femelle" are interchangeable in this context, as are the two terms rien/femelle. Such a view, however, is not truly her own. By calling herself a "nothingness" or a "tiny little thing" (216) as she does in the English version, Bouche is simply repeating a pattern of masculine superiority that is culturally acquired: she will never truly have a voice as a subject because she was born an object and any attempt to overturn the male/female hierarchical order will result in failure. In her opening statement, Bouche presents herself as apparently in line with the rules of patriarchy that consider females as less valuable than males. The birth of a girl is a less fortunate event than the birth of a boy: according to this cultural paradigm, Bouche is worthless and shall remain voiceless for the rest of her life.

The text seems to support this theory by presenting Bouche's birth as a series of negative events. This child arrived before her time and was the product of a mere sexual encounter between two people who abandoned her and who had no parental role during her infancy and beyond: "père mère fantômes ... pas trace... lui filé ... ni vu ni connu ... pas plus tôt boutonnée la braguette ... non, point d'amour" (82). For many Beckettian characters, from Winnie in Oh les beaux jours to Hamm in Fin de partie, the birth of a new life, is not a blissful event but rather an act of cruelty which will lead to a life of misery. ${ }^{4}$ Therefore, Bouche's birth is characterized, both grammatically and semantically, by negation and absence. No trace of the father, no love. Her beginnings can only be defined by what was not, just as in her present condition, her story can only be told by what she is not ("pas moi").

Through her speech, Bouche displays a sense of disintegration of the self. The insistence on "she," "not I" (the original English title of the play) reproduces, by a fairly obvious pun, the physical reality suggested by the title. The voice who speaks is "mouth," "not eye:" she is a piece 
separated from the rest of the body and forced to exist independently from it. Indeed, the reiterate use of "elle" is indicative of Bouche's sense of alienation from herself and from the world. The character is haunted by a sense of not belonging, of having lost her direction, as shown by memories of her drifting silently through a supermarket, a courthouse, and a home. In recounting the wanderings of her silent days, Bouche recalls that words came to her before she reached the prairie, the site of a longawaited linguistic rebirth. The sound of a bumblebee in this open space interrupts the quiet of her surroundings and marks her transition towards speech:

Oui ... silence de tombe à part le bourdon ... soi-disant ... quand soudain elle sent venir des - ...quoi? ...qui? ... non! elle! ... (pause et deuxième geste) ... sent venir des ... des mots ...imaginez ! ... des mots ! ... une voix que d'abord ... elle ne reconnait pas ... depuis le temps ... puis finalement doit avouer ... la sienne ... nulle autre que la sienne (86-87).

When the linguistic epiphany finally occurs, Bouche struggles to find her voice and fails to recognize the words she utters as her own. When attempting to invent patterns of a new, viable feminine discourse, she is initially confronted with the inability to engage in verbal practices that can adequately represent her. Yet, her voice gradually builds upon itself, one word after another, leading to the creation of a new story that Bouche will eventually tell in her own words.

This new story and the character's first encounter with language happen in an open and neutral space, the aforementioned field which returns periodically in her monologue. The closed spaces she had named, from the home to the supermarket to the courthouse, find her paralyzed and unable to utter a single word. The home in particular, as Kathleen O'Gorman remarks, "is the traditional site of the female subjugation to the law of the father who relegates her to the status of property" (81). By finding herself in the field, Bouche is free of spatial and socio-cultural boundaries: there, she can transgress the rules of a system that would want her conforming to the socially imposed role of wife, mother, and homemaker. The price to pay for non-conformity is exemplified in the reference to the courthouse and in Bouche's appearance in front of the judge. When called upon to defend herself for (presumably) having transgressed an acceptable unspoken code of feminine behavior, she displays a passive and victim-like attitude:

ce jour au tribunal ... qu'avait-elle à dire? Coupable ou non coupable? ... debout l'accusée ... répondez, l'accusée ... plantée là, ... les yeux dans le vide, bouche bée comme d'habitude ... attendant qu'on l'emmène ... (92). 
Although the reasons for her being brought to court are not clear, her crime is seemingly one of insubordination to patriarchal laws. Confronted with the power of male authority in a place (the courthouse) where women feel notoriously intimidated, Bouche has no choice but to remain silent.

During her voiceless years and through her peregrination from one place to the next, Bouche strives to find a center of balance for herself: technically, being just a fragment of a woman's body, she does not entirely belong to a feminine episteme and therefore cannot adhere to a specifically feminine behavioral paradigm. Furthermore, her first attempts at speech occur within a male-dominated verbal system which represses her feminine voice. As O'Gorman explains, "the first intelligible words Mouth speaks indicate the female displacement within the phallic order" (78). For this very reason, "she cannot assume a subject position within this order, cannot challenge the dominant discourse within which she has been inscribed" (79). Her linguistic displacement within the phallic order and the necessity to replace it with a new pattern of feminine discourse is emphasized by the reference to the lavatory where Bouche goes to "empty" herself, both physically and linguistically. This passage, which immediately follows the aforementioned mock trial, represents another instance of verbal epiphany: language gushes out of the character's body with a violence which is cathartic and liberating at the same time: "envie de raconter ... alors sentir comme une folle se jeter sur le premier venu ... la cuvette la plus proche ... s'y vider... . ce flot continu" (93). The stream mentioned in this passage is intentionally undefined and can equally be read as an outpour of words, vomit or menstrual flow (ce flot continu). The latter appears particularly relevant in this context since Bouche, who functions primarily as a mouth, can also be seen as representing a woman's reproductive organ. This component is more powerful in the play's television adaptation, which allows for close-ups of the moving lips, than in the theatrical version where the audience is necessarily positioned at a certain distance from the stage. ${ }^{5}$ Nonetheless, Bouche's metonymical function as the female sexual organ remains a powerfully suggestive image: in this sense, the continuous flow would indicate a woman's non-fertile time of the month. The menstrual cycle is a time during which the uterus restores its fecundity and later prepares for possible procreation. Similarly, after years of linguistic sterility, Bouche renews herself and experiences a period of fertility generating life through speech.

The character's newly found words are essential in filling the blank canvas of her feminine identity. Her story underscores her refusal to succumb to a linguistic absence. The often hysterical account of the events 
that develop between the time of her birth and her reaching the age of seventy does not follow a linear order and is deliberately built on a series of analeptic and proleptic segments. The account of Bouche's birth at the opening of her monologue is immediately followed by considerations about her old age and by the recollection of the yet unexplained linguistic awakening in the prairie. This last pivotal event is curiously placed in an anticlimactic position, at the opening of the play, and is built on the presence of opposing images of darkness and light, to signify the split identity of the speaker herself: "soudain ... peu à peu... tout s'éteint, toute cette lumière matinale ... début avril ... et la voilà dans le - ... quoi? qui? non! ... elle! ... (pause et premier geste) ... la voilà dans le noir" (82). The choice of April as the time for this episode is indicative of Bouche's refusal of a paradigmatic use of language. Conventionally associated with spring and images of rebirth and fertility, here April is connected with darkness. Visually and syntactically, the noun is placed in between images of gloominess (tout s'éteint/noir), thus overturning its archetypal signification which sees it as the month of light and joyful beginnings.

Bouche's speech turns the month of April in particular and spring in general from the season of life to the season of death. ${ }^{6}$ The word undergoes a process of transformation, an interrogation of reality similar to that of abstract art, according to Pascale Casanova who, Beckett l'abstracteur, states:

pour rompre avec la signification et le référent, inhérents au langage, Beckett ne travaille pas sur la matérialité sonore du mot: il est conduit à mettre en cause, les unes après les autres, toutes les conditions de possibilité ordinaires de la mémoire, l'imagination, le sujet, la narration les personnages, la psychologie, l'espace, le temps (9)

Words are familiar and yet estranged: logical connections are undermined, and the denotative value of language is questioned. More examples of this mechanism, which leads to a general displacement of meaning, can be found in Bouche's multiple references to God throughout the play. The story of how the character came to speak is permeated with Christian overtones. When reconstructing the birth of her language, she paraphrases the Bible to fit her own story of aphasia:

car première chose l'idée... oh bien après...brusque illumination ... dressée qu'elle avait été à croire ... avec les autres abandonnés ... en un Dieux ... (bref rire) ... miséricordieux (bon rire) ... première chose donc l'idée ... oh bien après ... brusque illumination ... que la voila punie ... en voie d'être punie (83) 
The biblical "in the beginning was the word" is echoed in "première chose l'idée." The God who created the world and the word is a falsely merciful father who punishes her for having defied his power. The referential meaning of miséricordieux is immediately annulled by Bouche's sarcastic laugh before and after she pronounces the word. The God she portrays is a vindictive figure, a male deity who does not show mercy, not unlike the previously mentioned judge in the court house: both accuse Bouche of crimes and sins she never committed and are unwilling to listen to her defense.

The crime and the sin remain equally unspecified: nonetheless, in feminist terms, it can be argued that, in allowing herself to create new words, Bouche has taken the role of God upon herself. By producing her own language, she has challenged that same law of the father that wanted her silent and is punished for having gone beyond the limits of what is permissible for a woman. As Susan Gubar observes, "Christianity, as feminist theologians have shown us, is based on the power of God the father who creates the natural world of generation out of nothing" (293). Creation is a masculine privilege. Women cannot create, they do not have the power to produce anything new: they can be art objects but not artists or creators themselves. During her aphasic years, Bouche was denied any possibility of creation. Her body's desires remained unvoiced and her sexuality was annulled, as she recounts: "alors qu'elle était presumée ... toute évidence ... éprouver du plaisir, elle n'en éprouvait aucun" (83). The episteme which Bouche reproduces in her discursive practices stems from the patriarchal notion that female desire is to be suppressed and denied. Hence, for the character, coming to language signifies regaining her once suppressed sexual awareness: her new identity will be constructed regardless of the laws of a masculine discourse that would want her body and language to remain silent. Indeed, Bouche's speech, although shaky and uncertain at first, eventually explodes into an endless stream of words and into a linguistic jouissance. In her attempts to make new (fertile) sense out her language and her body, she does what Cixous describes in "Le Rire de la Méduse:"

Si la femme a toujours fonctionné "dans" le discours de l'homme, signifiant toujours renvoyé à l'adverse, signifiant qui en annihile l'énergie spécifique ... ., il est temps qu'elle disloque ce "dans," qu'elle l'explose, le retourne, le saisisse, qu'elle le fasse sien, le comprenant, le prenant dans sa bouche à elle. Que de ses dents à elle elle lui morde la langue, qu'elle s'invente une langue pour lui rentrer dedans (49). 
Piece by piece, Bouche creates a feminine speech that allows her to become the sole protagonist of the play in both body and language: her audience (Auditeur), who is male, never utters a word. She is the sole creator of the speaking act and is the only character who can keep absence from happening. The "sense" of her verbal production, which lacks logic and order, is precisely in the attempt to replace absence with a tangible presence: her words fill the theatrical space while at the same time building the framework of her new identity.

The last few lines in Pas moi reinstate several leitmotifs of the play and confirm the choice of a speech pattern that refuses to adhere to the rules of a logocentric and linear discourse: "Dieu est amour ... bonté intarissable ... chaque matin nouvelle ... rendue à la prairie .... matin d'avril ... visage dans l'herbe ... seule au monde ... avec les alouettes ... reprendre la ... repartir de -" (94-5). Circularly, Bouche goes back to the April morning of her linguistic birth, to her loneliness and isolation, and to the God who had punished her. In particular, God appears in her final words but only as a cliché and an empty signifier ("Dieu est amour"). Again, such statement needs to be read through a semantic reversal. In Bouche's value system, God is not love. He, like the judge in the courthouse, or the father who abandoned her, has shown her no love and has punished her unfairly. A few moments earlier in her speech, Bouche had acknowledged the uselessness of her prayer which was "pas entendue ... trop faible" (94). ${ }^{7}$ The act of praying in this context becomes a futile ritual. As Knowlson and Pilling rightly argue, "like Winnie in Happy Days, Mouth seeks comfort from familiar phrases which can, however, provide her with no sense of permanent release" (202). When she attempts to revert back to that same language of patriarchy which her speech is undermining, she discovers that those words and phrases are estranged from her. For this reason, she abandons them in favor of her own fragmented speech which better describes her feminine identity in the making.

The quest of a woman (or part of one) who seeks to define herself as a speaking subject leads to questions of gender and identity in the play. Contrarily to what Beckett repeatedly stated about the irrelevance the sex of his characters, Pas moi confirms that gender issues in Beckett's work cannot be ignored. ${ }^{8}$ Bouche and Auditeur find their origin as characters in two specific figures that the author had observed in two distinct occasions. Deirdre Bair recalls that the idea of a mouth separated from the rest of the body derives from "The Beheading of St John," a painting Beckett had seen in Malta shortly before the play was written. Similarly, Auditeur, all dressed in black, was inspired by a scene he had witnessed in Morocco 
of an Arab woman wrapped in a djellaba who was anxiously waiting for her child to arrive on the school bus. He was struck by her "attitude of intense waiting" and by her gestures of flapping "her arms aimlessly against her sides" (622). These two powerful images were reworked to fit the characters' roles and relations in the play. Notably, the gender of the two figures at the origin of Bouche and Auditeur was reversed. The head of St John became the mouth of a woman and the female figure in the djellaba became a male listener.

Bouche's speech is unmistakably and deeply feminine and a gender role reversal in the play would simply not be possible. Additionally, the character, as Beckett himself stated, has its direct origin in the idiosyncrasies of the "Irish bag lady." As he explains, "there were so many of those old crones, stumbling down the lanes, in the ditches, besides the hedgerows. Ireland is full of them. And I heard her saying what I wrote in Not I. I actually heard it" (Knowlson, Damned to Fame 522). Bouche is a part of a woman whose painful experiences of subjugation to patriarchal laws, denial of speech, and suppression of sexuality are unmistakably feminine. In particular, Bouche's life-long verbal struggle to rise beyond a paralyzing linguistic semiotic discourse inscribe the character inside an all-feminine episteme. Despite her interrupted language, she is able to construct a feminine moi outside and beyond the rules of an inadequate phallic order. Bouche's coming to speech and the creation of a viable "self" can be summarized again by Hélène Cixous' experience of coming to writing. In addressing the challenges female speakers face when attempting to establish a feminine identity through speech, she asks herself: "je suis ... qui serait parler comme Dieu? Pas je .... . Ce que j'étais, était un tourbillon de tensions, une série d'incendies, dix mille scènes de violence" (26). Cixous labels "je suis" as the language of God the father, as a model of verbal communication which does not belong to woman and therefore cannot define her. Bouche experiences the same inability to belong to her body, to language, and consequently, to the outside world. Feeling estranged from the conventional first person subject pronoun, she can only attempt to verbally define herself through pronoun other than "je." For this reason, she will never be able to let go of "elle:" the pronoun sets her apart as something other than " $I$ " while at the same time identifying her as a feminine subject.

In discussing issues of representation of the body through language, Helena Michie argues that "since our knowledge of the self is constituted in and by discourse, we can only construct for ourselves a body in pieces, a corps morcelé" (149). Bouche's body is indeed morcelé, as is her speech. 
The mouth is normally the vehicle of expression of the thoughts produced by the brain. In the play, however, there is no head, only a mouth with its lips, teeth and tongue. In this sense, language and body follow the same pattern of disintegration: a body in pieces can only express itself through pieces of language.

Nonetheless, despite her linguistic fragmentation, Bouche successfully creates her own "rules" of play. Her speech destroys the logos and all its foundations while working to rebuild a functioning feminine linguistic system. Inevitably, during this process, Bouche's language sounds like a broken record and falls into a series of repetitions and ellipses. Her words reject conventional syntactic and semantic channels and replace them with minimal grammatical structures made of verbs in the infinitive, nouns without verbs, and participes présents: "le cerveau ... plein délire là aussi ... à vouloir y trouver un sens ... ou y mettre fin ... ou dans le passé ... trifouillant dans le passé ... petites scénettes éclair ... balades surtout, toute sa vie à se balader " $(89-90)$.

Such seemingly chaotic linguistic choices are not the result of a semiotic paralysis on the part of the speaking subject: on the contrary, they are indicative once more of Bouche's refusal to inscribe her language production within a logocentric system of speech. Similarly, her final refusal to relinquish the use of "elle" does not imply a defeat on her part. At the end of her monologue, Bouche remains unable to abandon the use of the third person pronoun and returns to "elle" a few moments before the play closes. Through such refusal, Bouche states the impossibility to write her history within the phallic order. Producing speech outside male-centered discursive practices is not a fruitless effort and the play does not portray an irreversible linguistic crisis. Pas moi shares in the breakdown of referentiality that characterizes Beckett's "mature" writing while at the same time proving the impossibility of achieving a completely non-referential type of theatrical representation. Bouche may miss all the elements that make up a conventional character in theater (body, movement, psychology) but she ultimately proves with her speech that she can break the silence she was originally destined for.

The powerful image of the dismembered body of a woman who tries to reconstruct her "self" by letting her mouth recount her coming to language, leads to an interrogation about the female body and its ability (or inability) to produce meaning through gesture and verbal discourse. A whole identity may never be constructed, as the body's wholeness is irremediably lost. Nonetheless, words remain at the core of the theatrical performance and justify Bouche's existence as a character. Although she 